OPEN ACCESS

Edited by:

Krina K. Patel,

University of Texas MD Anderson

Cancer Center, United States

Reviewed by:

Fabian Benencia,

Ohio University, United States

William K. Decker,

Baylor College of Medicine,

United States

*Correspondence:

Lana E. Kandalaft

lana.kandalaft@chuv.ch

Specialty section:

This article was submitted to

Cancer Immunity and Immunotherapy,

a section of the journal

Frontiers in Immunology

Received: 14 August 2018 Accepted: 22 March 2019

Published: 11 April 2019

Citation:

Mastelic-Gavillet B, Balint K, Boudousquie C, Gannon PO and Kandalaft LE (2019) Personalized Dendritic Cell Vaccines-Recent Breakthroughs and Encouraging

Clinical Results.

Front. Immunol. 10:766.

doi: 10.3389/fimmu.2019.00766

\section{Personalized Dendritic Cell Vaccines-Recent Breakthroughs and Encouraging Clinical Results}

\author{
Beatris Mastelic-Gavillet, Klara Balint, Caroline Boudousquie, Philippe O. Gannon and \\ Lana E. Kandalaft*
}

Department of Oncology, Center for Experimental Therapeutics, Ludwig Center for Cancer Research, University of Lausanne, Lausanne, Switzerland

With the advent of combined immunotherapies, personalized dendritic cell (DC)-based vaccination could integrate the current standard of care for the treatment of a large variety of tumors. Due to their proficiency at antigen presentation, DC are key coordinators of the innate and adaptive immune system, and have critical roles in the induction of antitumor immunity. However, despite proven immunogenicity and favorable safety profiles, DC-based immunotherapies have not succeeded at inducing significant objective clinical responses. Emerging data suggest that the combination of DC-based vaccination with other cancer therapies may fully unleash the potential of DC-based cancer vaccines and improve patient survival. In this review, we discuss the recent efforts to develop innovative personalized DC-based vaccines and their use in combined therapies, with a particular focus on ovarian cancer and the promising results of mutanome-based personalized immunotherapies.

Keywords: dendritic cells, vaccines, cancer, immunotherapy, neo-antigens

\section{INTRODUCTION}

Dendritic cells (DC) are the most potent professional antigen-presenting cells (APC) and play critical roles in regulating the innate and adaptive immune responses (1). In their immature state, DC patrol the tissue microenvironment and become activated in the presence of foreign pathogens. This activation occurs following stimulation by exogenous danger signals via pattern recognition receptors (PRR) such as Toll-like receptors (TLR) $(2,3)$ and leads to DC migration to the draining lymph node and the presentation of the processed epitopes to T cells (4). During the $\mathrm{T}$ cell activation, DC engage the T-cell receptor (TCR), secrete specific cytokines and stimulate the immune responses toward TH1, TH2, or Tregs depending on the cytokine environment. Due to their proficiency at antigen cross-presentation (i.e., the presentation to both $\mathrm{CD} 4^{+}$and $\mathrm{CD} 8^{+} \mathrm{T}$ cells), DC have been used as vaccine platforms to induce anti-tumor cytotoxic T lymphocyte (CTL) CD8 immune responses (5-8).

Various types of DC-based vaccines have been evaluated in clinical trials. The most commonly used preparation involves the reinfusion of ex-vivo derived DC pulsed with tumor-associated antigens (TAAs) or tumor cell lysates and stimulated with a defined maturation cocktail. In the earlier trials, the gold standard maturation cocktail included the pro-inflammatory cytokines TNF- $\alpha$, IL-1 $\beta$, and IL-6 in combination with prostaglandin E2 (PGE2) (8-10). However, despite the important roles of PGE2 in promoting DC migration (11) and in enhancing T cell proliferation (12), it has also been shown that PGE2 may induce differentiation of regulatory T cells (13), 
increase the expression of the pro-tolerogenic enzyme indoleamine 2,3-dioxygenase (IDO) (14), and may limit IL12 p70 production (15). As these PGE2-related activity may curtail the anti-tumoral immune response, alternative methods of ex vivo maturation of DC have been explored such as the triggering of co-stimulatory pathways (e.g., CD40-CD40L) (16) and the activation of the TLR using agonists such as poly IC (TLR3) (17), resiquimod (TLR7/8) (8) and 3-O-deacylated monophosphoryl lipid A (MPLA) (18), a modified TLR4 agonist with less toxicity than LPS. Moreover, DC subsets have been directly targeted in vivo by administration of TAAs directly to DC or by intra-tumoral administration of immunomodulatory molecules to activate local DC.

Although, DC-based vaccinations looked promising after Sipuleucel-T (Provenge ${ }^{\circledR}$ ) approval in 2010, a DC-based immunotherapy for the treatment of advanced prostate cancer (19), unfortunately, the vaccination against established malignancies has generally shown limited clinical benefit. There are a number of potential factors that can impact the efficiency of DC-based vaccines. For instance, there is a reduction TAAs expression by tumor cells leading to immunosuppression and the immune evasion of cancer cells. Tumor cell elimination may also be blunted by the immune suppressive barriers overexpression, such as checkpoint receptor signaling (CTLA-4, PD-1/PD-L1) and immunomodulatory cellular subsets [Tregs and myeloidderived suppressor cells (MDSCs)] $(20,21)$. Moreover, there are evidences of defects in both the number and functions of DC subsets, which facilitate tumor progression and immune evasion (22-29). Overall, the transition of DC from an in vitro cell culture to an in vivo immunosuppressive environment may alter the effectiveness of DC-based immunotherapy.

Therefore, ongoing trials using DC-based vaccines are evaluating the use of combined immunotherapies to favor $\mathrm{DC}$ activation and promote $\mathrm{T}$ cell functions, and overcome tumor immune evasion. The Indian government agency (CDSCO-Central Drugs Standard Control Organization) recently approved in 2017 an autologous monocyte-derived and tumor lysate-pulsed mature DC-based vaccine (APCEDEN ${ }^{\circledR}$ ) for treatment of four cancer indications (prostate, ovarian, colorectal and non-small cell lung carcinoma) (30). The multicentric phase II clinical trial by Bapsy et al. (31) demonstrated that this formulation was safe and well-tolerated in patients with refractory solid tumors. Moreover, the efficacy profile of APCEDEN ${ }^{\circledR}$ therapy demonstrated a survival benefit of $>100$ days (30).

\section{HUMAN BLOOD DENDRITIC CELLS}

DC originate from the common myeloid bone marrow progenitor cells and can be found in both, lymphoid and nonlymphoid tissues in an immature state (1). DC are heterogeneous and consist of multiple specialized subtypes, which are defined based on their phenotypic and functional characteristics,

Abbreviations: DC, Dendritic cell; APCs, Antigen-presenting cells; CTL, Cytotoxic T lymphocyte; TAAs, tumor-associated antigens; MoDC, Monocytederived DC; OS, Overall survival; TILS, tumor infiltrating lymphocytes. including morphology and immunological features (expression of surface markers, cytokines, chemokines, and transcription factors). The homology of human DC and mouse DC populations have been extensively studied using transcriptional profiling (32-36). In humans, all DC express high levels of MHC class II molecules (HLA-DR), and lack lineage-specific surface markers for $\mathrm{T}$ cells (CD3), B cells (CD19/20), and natural killer cells (CD56). The DC subtypes found in the blood are myeloid $\mathrm{DC}(\mathrm{mDC})$ (also termed $\mathrm{CD} 11 \mathrm{c}^{+}$conventional $\mathrm{DC}, \mathrm{CDC}$ ), which can be further divided into $\mathrm{CD} 141^{+} \mathrm{mDC}$, $\mathrm{CD}^{+} \mathrm{c}^{+} \mathrm{mDC}$, and $\mathrm{CD}_{123^{+}}$plasmacytoid $\mathrm{DC}$ (pDC) (37). The $\mathrm{CD}^{+} \mathrm{c}^{+} \mathrm{mDC}$ account for the majority of the $\mathrm{mDC}$ population in the human blood representing approximately $1 \%$ of all mononuclear cells, with the $\mathrm{CD} 141^{+} \mathrm{mDC}$ representing only $0.1 \%$. Compared with $\mathrm{CD}_{141^{+}} \mathrm{mDC}$, the $\mathrm{CD} 1 \mathrm{c}^{+} \mathrm{mDC}$ have an inferior capacity to cross-present antigen to $\mathrm{CD} 8^{+} \mathrm{T}$ cells $(35,38)$. Human $\mathrm{CD} 141^{+} \mathrm{DC}$ are homologous to the mouse cross-presenting $\mathrm{CD} 8 \alpha^{+} / \mathrm{CD} 103^{+} \mathrm{DC}$, and are characterized by the exclusive expression of XCR1 and Clec9A $(33,39-43)$. The pDC are specialized producers of type I interferons in response to viruses (44) and can, on one end, induce Tregs expansion and tolerance $(45,46)$, while effectively cross-present antigens to CTL (47-49). Using mass cytometry (i.e., CyTOF), Guilliams et al. identified that the combination of the two markers (CADM1 and $\mathrm{CD} 172 \mathrm{a}$ ) could be used as flow cytometry markers to identify the conventional subsets of $\mathrm{mDC}$ across tissues and species (human, macaque and mouse) (50). Thus, CD141 $1^{+}$ DC can be defined as CADM $1^{\text {hi }} \mathrm{CD} 172 \mathrm{a}^{\text {lo }}$, while the $\mathrm{CD} 1 \mathrm{c}^{+}$ $\mathrm{mDC}$ correspond to $\mathrm{CADM} 1{ }^{\mathrm{lo}} \mathrm{CD} 172 \mathrm{a}^{\text {hi }}$ cells. Notably, the conventional identification of $\mathrm{mDC}$ or $\mathrm{pDC}$ (37) has lately been challenged by a study, which, using single-cell transcriptome profiling, demonstrated that human blood DC could be further stratified into six distinct populations (51). This increasing knowledge about DC subsets will certainly be exploited for the design of novel strategies to improve the clinical efficacy of cancer vaccines.

The isolation of DC subset is another for the generation of DC-based vaccine has also improved over the years. Initially, DC subsets were isolated directly ex vivo from the peripheral blood to produce DC-based vaccines for immunization of B celllymphoma patients against their TAAs (52). As DC have a low frequency in peripheral blood, low numbers of DC were isolated using this method. Nowadays, most clinical studies employ monocyte-derived DC (MoDC) in the generation of DC-based vaccine because of the relative ease at obtaining sufficient number of cells from peripheral blood and their functionality $(53,54)$. MoDC are a subset of DC exhibiting common features with cDC (55), including the ability to migrate, to potently stimulate $\mathrm{CD}^{+}$and $\mathrm{CD}^{+}{ }^{+} \mathrm{T}$ cells, to produce key cytokines (IL-1, IL6 , TNF- $\alpha$, IL-12, and IL-23) (56), and to express cell surface markers such as CD11c and MHC II (55). Autologous MoDC can be obtained by culturing human peripheral blood monocytes $\left(\mathrm{CD} 14^{+}\right)$in the presence of GM-CSF and IL-4 (57) with the resulting vaccines eliciting tumor-specific $\mathrm{T}$ cell responses and some clinical efficacy (56).

With recent technological advances in isolation of specific immune cell populations, second generation DC vaccine have 
focused on the collection of blood-derived primary DC subsets. As previously mentioned, naturally circulating DC have a low frequency in peripheral blood ( $<1 \%$ of leukocytes). Nonetheless, there exist significant transcriptional and functional differences between the blood-derived DC in comparison with the in vitro generated MoDC suggesting that blood-derived DC may be superior for therapeutic vaccination $(32,58)$. Early phase I results suggest that vaccination with peripheral blood-derived $\mathrm{pDC}$ or $\mathrm{mDC}$ is safe and well-tolerated amongst patients with advanced-stage melanoma (59), prostate carcinoma (60) or acute myeloid leukemia (61). One such trial is based on a novel type of blood-derived DC vaccine is being assessed within the collaborative European project entitled "Professional crosspriming for ovarian and prostate cancer" (PROCROP). For this trial, a $\mathrm{CD} 141^{+}$subset of blood-derived $\mathrm{mDC}$, which has superior capacities at cross-presenting TAAs to $\mathrm{CD} 8^{+} \mathrm{T}$ cells $(39,42,62)$, is being evaluated as a personalized DC vaccine.

Altogether, clinical trials have yet to prove that blood-derived DC vaccines are more efficacious than in vitro generated MoDC (63). For instance, the development of second generations of DC-based vaccines may also face multiple technical challenges such as the limited availability of cells that can be purified, the large amount of blood or leukapheresis to be collected, and the negative effects of chemotherapy that may reduce the number of DC in the peripheral blood (64).

\section{DENDRITIC CELL DYSFUNCTION IN CANCER}

Optimal DC function is necessary for the initiation of protective anti-tumor immunity. Yet, it is known that immunosuppressive factors expressed by the tumors cells, including $\operatorname{IDO}(65,66)$, Arginase I (67), IL-10 (68, 69), TGF- $\beta(23,70)$, PGE2 $(71,72)$, and VEGF (73-77), can impair the differentiation, maturation, and function of the host DC (78-80), which may become tolerogenic and favor the stimulation of regulatory $\mathrm{T}$ cells $(81,82)$. For instance, high level of intratumoral $\mathrm{pDC}$ is associated with poor disease outcome across several tumor types $(83,84)$. The impairment of DC differentiation $(80,85)$, and the resulting inadequate antigen-presenting functionality of DC, contributes to $\mathrm{T}$ cell anergy or exhaustion is well documented in cancer. In a breast and pancreatic cancer study, tumor-derived granulocytestimulating factor induced alterations in the development of $\mathrm{CD} 141^{+} \mathrm{DC}$, which were associated with impaired $\mathrm{CD} 8^{+} \mathrm{T}$ cell responses and correlated with poor clinical outcomes (86). An additional mechanism contributing to the impaired antigen processing ability of intra-tumoral DC is the accumulation of pathological amount of lipid by the DC due to up-regulated expression of scavenger receptor A (SR-A) (87). These lipid-laden DC have reduced capacity to stimulate allogeneic $\mathrm{T}$ cells (87).

It was previously demonstrated that DC derived from patients with advanced cancer are weak stimulators of $\mathrm{T}$ cells compared to healthy volunteers (88). In some tumors, as cancer progresses, tumor-infiltrating DC accumulate and switch from immunostimulatory to regulatory phenotypes (23), and correlates with the increased expression of negative costimulatory molecules such as TIM3 (89), PD-L1 and PD1 (90) as well as the production of L-Arginase (91). In fact, this is a predominant mechanism of DC dysfunction in ovarian carcinoma, with PD-1 ${ }^{+} \mathrm{PD}-\mathrm{L} 1^{+} \mathrm{CD} 277^{+} \mathrm{DC}$ accumulating in the tumor over the course of the disease $(90,92)$. The increased expression of PD-1 was shown to affect the function of DC by inhibiting NF- $\kappa \mathrm{B}$ activation, and was associated with decreased T cell activity and reduced tumor-infiltrating $\mathrm{T}$ cells in advanced cancer (93). CD277 was shown to be universally expressed in ovarian cancer-infiltrating DC and may affect the expansion of TCR-stimulated T cells.

Therefore, the immunosuppressive DC, controlled by the tumor microenvironment, plays an important role in supporting tumor progression, and probably limiting the success of DCbased vaccine in cancer patients. There is increased awareness on the influence of age-related changes on the development of tumors and on treatment prognosis. Aging has already a profound effect on DC function, affecting numbers and functions of pDC (94), and inducing substantial changes in gene expression profile of CD1c ${ }^{+} \mathrm{DC}$ as illustrated by significant down-regulation of antigen presenting and energy generating genes (95). Thus, to overcome systemic immune dysfunction and augment DCinduced responses in vivo, many investigators are combining DC-based vaccines with tumor-damaging agents or considering the use of DC-based vaccines to treat earlier in the course of the disease (96). Notably, combining CD40 agonists with TLR3 activation was shown to be sufficient to reverse the immunosuppressive phenotype of tumor-infiltrating DC into APCs capable of priming anti-tumor T cell responses (97).

\section{ACTIVE INGREDIENTS OF DC-BASED CANCER VACCINES}

\section{Tumor Antigens}

TAAs are a crucial component of DC vaccines as they represent the targets for CTL-generated anti-tumor immune response. Non-mutated self-antigens resulting from over-expression of tissue- or lineage-specific genes induced by transformation induce low $\mathrm{T}$ cell reactivity due to central tolerance mechanisms. Conversely, mutated neo-antigens are generated by somatic mutations due to the tumors inherent genetic instability rendering them tumor-specific and private, with the advantage of being recognizable for $\mathrm{T}$ cells and not impacted by central tolerance.

\section{Defined Antigens}

The most widely used cancer vaccines tested so far were based on defined, shared TAAs (e.g., MART-1, gp100, CEA, PSA, p53, NYESO-1, MAGE-A3), which are HLA restricted (98-103). Both, individual and the combination of several defined antigens were tested, but only achieved limited clinical efficacy (104-106). A potential disadvantage of immunotherapy targeting one or few defined TAAs is the possibility of rapid development of tumor escape variants that lose the expression of these epitopes (107). Using multiple (defined or undefined) antigens as vaccine targets may be crucial for achieving significant clinical benefit and may overcome the challenge of tumor escape via antigen-loss. 


\section{Neo-Antigen-Targeted Approaches}

The high mutational rate of tumor cells results in the expression of neo-antigens that are tumor specific. The identification of patient specific TAAs, including both shared tumor antigens and neo-antigens, is now possible using next-generation sequencing (NGS) and bioinformatics tools (e.g., NetMHC) (108) complemented or not by direct isolation of HLA-bound peptides (immunopeptidome) and mass spectrometry (MS) analysis (109). The personalized cancer vaccine can be manufactured based on neo-antigens that have been identified and used to manufacture peptides or RNA for the pulsing of DC. Nonetheless, two major challenges arise from this approach: the time between tumor resection and first vaccine injection, which can reach several months, and the cost of the neo-antigen identification process.

Three recent Phase I clinical trials confirmed promising potential of personalized cancer vaccines based on neo-antigens (110-112), with the study by Carreno et al. utilizing DC-based vaccine (110). Whole-exome sequencing was carried out to identify somatic mutations in tumors from three patients with melanoma and short peptides coding for seven neo-antigens were pulsed onto autologous DC. Despite the small sample size, the study proved that neo-antigen cancer vaccines could elicit neo-antigen specific $\mathrm{T}$ cell response with some patients showing stabilized or non-recurrent disease (110).

\section{Whole Tumor Preparations}

In indications where surgery can be performed as part of the treatment, the resected tumor tissue can be used as a source of patient-specific TAA by preparing a tumor cell lysate. Alfaro et al. used freeze-thaw lysis from biopsies to generate glioma-specific lysate (113). The treatment induced IL-12 production in each patient and circulating tumor cells markedly dropped in 6 of 19 cases with five patients experiencing disease stabilization (114). The immunogenicity of tumor cell lysate can be enhanced using alternative lysate preparation methods such as freeze-thaw, UV irradiation or oxidation treatment (115-120). Our group showed that tumor cells oxidation using hypochlorous acid $(\mathrm{HOCl})$ combined with freeze-thaw cycles results in primary necrosis of tumor cells, and increases immunogenicity of the resulting tumor lysate (121). The main advantages of using autologous tumor lysate as a source of TAAs are the absence of HLA restriction and the reduced time and cost of manufacturing in comparison to the neo-antigen prediction strategies.

\section{RECENT ACCOMPLISHMENTS IN PERSONALIZED DC-BASED IMMUNOTHERAPY}

\section{Current Treatment Strategies for Advanced Ovarian Cancer}

A DC-based vaccine generated by differentiation of autologous Mo-DC pulsed with $\mathrm{HOCl}$ oxidized autologous tumor cell lysate (OC-DC vaccine) was tested in platinum-treated, immunotherapy-naïve, recurrent ovarian cancer patients in a single-center, multi-cohort, non-randomized phase I trial (122). During the study, a total of 392 vaccine doses were administered intra-nodally under ultrasound guidance without serious adverse events. The results of the first of three cohorts was reported by Tanyi et al. (122). In this study, the DC-based vaccine was administered either alone, in combination with bevacizumab or in combination with bevacizumab and lowdose intravenous cyclophosphamide until disease progression or vaccine exhaustion. This OC-DC vaccine induced $\mathrm{T}$ cell responses (increased in IFN- $\gamma$ production) to autologous tumor antigens, which were detected in 11 of 22 evaluable patients on week 12. Moreover, this antitumor immune response was associated with significantly prolonged survival with increased neo-antigen specific $\mathrm{T}$ cells responses, both previously recognized and non-recognized neo-epitopes.

Overall from the 25 patients treated two (2) patients showed partial response and 13 patients experienced stable disease, which persisted for a median of 14 months from enrolment. Of note, vaccine responders experienced significantly longer progressionfree survival (PFS) compared to non-responders patients. The 2-year overall survival (OS) rates of the responder patients was $100 \%$, whereas the 2 -year OS of non-responders was $25 \%$. The best results were obtained with the triple combination of vaccine plus bevacizumab and cyclophosphamide. This study demonstrated that the use of OC-DC vaccine was safe and elicited a marked antitumor immunity, including tumor-specific neo-antigens. Altogether, personalized DC vaccines using whole tumor lysate can drive responses to private antigens and, in combination with other immunotherapy treatments, can greatly improve clinical outcome.

\section{Promising Phase 3 Studies in Progress}

An exhaustive list of DC-based studies is available in Table $\mathbf{1 .}$ Notably, a phase 3 trial is currently testing DC vaccine loaded with autologous tumor lysate (DCVax-L) in patients with newly diagnosed glioblastoma following surgery as add-on to the standard of care combining radiation and chemotherapy (NCT00045968; Northwest Therapeutics). Patients are receiving temozolomide plus DCVax-L $(n=232)$ or temozolomide and placebo $(n=99)$. DCVax-L is administered intra-dermally six (6) times the first year and twice per year thereafter. Following recurrence, all patients are allowed to receive DCVax-L. The first reported results showed that the median OS was 23.1 months from surgery as compared with the 15-17 months achieved with SOC only in past studies (123). Only $2.1 \%$ of patients had a grade 3 or 4 adverse event related to the vaccination treatment. Due to its safety profile, this DC vaccine has the potential to be administered in a wide range of indications and applied in a wide range of combinations.

Another phase 3 study is currently evaluating the efficacy adjuvant vaccination using RNA-loaded autologous DC vaccine to treat patients with uveal melanoma (NCT01983748). This study will compare standard of care treatment with vaccination (8 intravenous of vaccine over 2 years).

Finally, a phase 3 study is currently evaluating active immunization in adjuvant therapy of patients with stage 3 melanoma with natural $\left(\mathrm{BDCA}^{+}\right.$) dendritic cells (nDC) pulsed with peptides (NCT02993315). Patients will receive nDC vaccine by three (3) intranodal injection per cycle for a maximum of three 


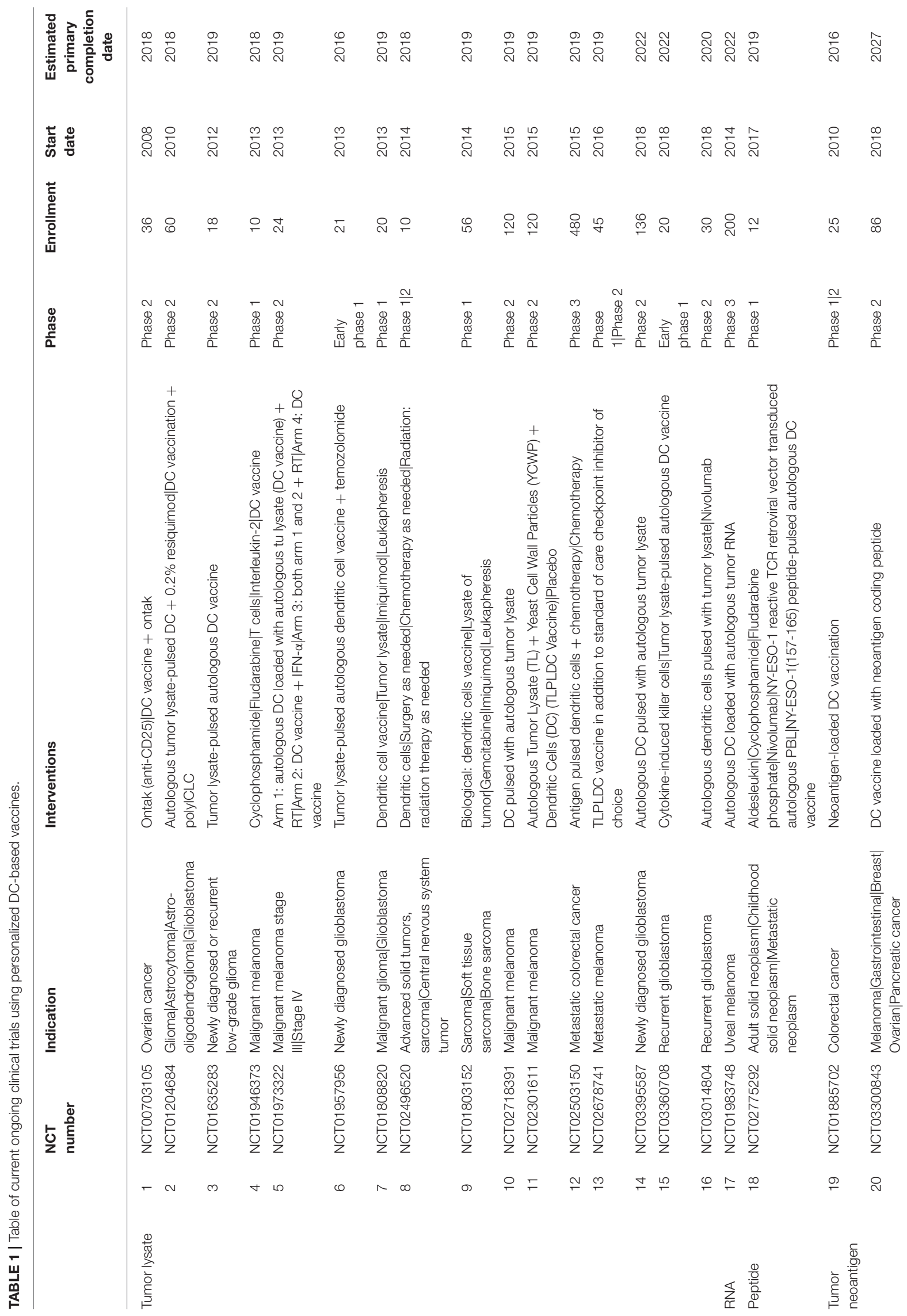


(3) cycles or placebo injections to determine if adjuvant $\mathrm{nDC}$ vaccination improves 2 -year RFS rate.

\section{PREDICTIVE MARKERS FOR THE CLINICAL EFFICACY OF DC-BASED VACCINES}

Another path to the improvement of DC-based vaccine efficiency is based on the identification of surrogate biomarkers of the triggered immune response against the tumor that would strongly and uniformly correlate to vaccine efficacy. Studies have identified different potential biomarkers of clinical responses to DC-based vaccination. For instance, in melanoma, two (2) candidate genes were identified with a predictive value for a positive outcome to a DC-based immunotherapy (124). The chemokine receptor CXCR4 and the receptor for the FC portion of IgD (CD32) were over-expressed in the lymphocytes cell membranes and in the monocyte populations in immunological responder patients as compared to non-responder patients (124). Higher CXCR4 protein expression was found in $\mathrm{CD}^{+} \mathrm{T}$ cells pre- and post- whereas higher CD32 protein expression in monocyte populations was identified in responder patients at pre-treatment time points (124). In a recent phase II study in patients with glioblastoma, DC vaccination induced a significant and persistent activation of $\mathrm{CD} 56^{\mathrm{dim}}$ cytotoxic NK cells, whose increased response was strongly associated with prolonged survival, while $\mathrm{CD}^{+} \mathrm{T}$ cells had only a poor contribution to anti-tumor responses (125). In NSCLC patients, the survival time was closely associated with the $\mathrm{BDCA}^{+}{ }^{+} \mathrm{DC} / \mathrm{BDCA}^{+}{ }^{+} \mathrm{DC}$ ratio in peripheral blood after $\mathrm{DC}$ immunotherapy (126).

Tumor-infiltrating lymphocytes (TIL) are examined extensively in various cancer types, including epithelial ovarian cancer, with their presence found to be an important prognostic factor (127-134). Additionally, in ovarian cancer, infiltrating Tregs in the tumor microenvironment correlate with poor prognosis (135-137). In the context of DC-vaccination, in glioma, the TIL content was identified as a predictor of clinical response (138). An increased overlay in the TCR repertoire of TIL and circulating T cells correlated with improved responses to DC-based vaccination and overall survival (138). Hence, the TIL content may be used as a selection tool to identify patients who could potentially benefit from DC vaccination therapy.

In terms of monitoring anti-tumor vaccine trials, a study by Kirkwood et al. found that functional assessment of $\mathrm{T}$ cells such as interferon- $\gamma$ production is preferable as opposed to frequency or phenotype of effector T-cells (139). In a multicenter study (ECOG E1696), where melanoma patients were treated with a peptide vaccine, there was a significant difference in OS by immune response status. Immune responders, patients whose $\mathrm{T}$ cells exhibited interferon- $\gamma$ response (against to one or more of the three antigens measured by ELISPOT) lived longer than the nonimmune responders (median OS, 21.3 vs. 10.8 months; $P=0.033$ ).

In conclusion, highly reliable molecular or cellular biomarkers of the clinical efficacy of personalized DC-based vaccines are still missing. Prospective longitudinal studies will help identify predictive prognostic and treatment-efficacy biomarkers using "Omics" data (140) and systems biology analysis. Therefore, there is an urgent need for clinical studies beyond phase II to demonstrate that DC-based vaccines can induce durable objective responses and improve long-term survival in cancer patients, and maybe identify strong correlate for all malignancies.

\section{CONCLUSIONS}

The development and success of DC-based immunotherapies has been hampered by several factors; (1) the immunosuppressive tumor microenvironment, particularly in advanced stage of the disease (2) the limited capacity of systemically administered DC to localize to the tumor-draining lymph nodes, (3) the low avidity of TAAs-specific T cells, and (4) the lack of reliable prognosis biomarkers. The rapidly increasing knowledge about DC subsets and the tumor-induced suppressive microenvironment must be exploited to design novel and improved cancer vaccines. The future of DC vaccines will certainly rely on combination therapies. As discussed in this review, recent studies have shown the great potential of such strategies, especially when using personalized DC vaccines. Overcoming the cancer immunosuppressive environment will reveal the real therapeutic potential of such DC vaccine.

\section{AUTHOR CONTRIBUTIONS}

BM-G and KB wrote the manuscript. All authors, BM-G, KB, $\mathrm{CB}, \mathrm{POG}$, and LEK contributed to manuscript revision, read and approved the submitted version.

\section{ACKNOWLEDGMENTS}

The research leading to these results has received funding from the European Commission's H2020 Programme and the Swiss Government under grant agreement number 635122, and a grant by the Ovacure Foundation.

\section{REFERENCES}

1. Banchereau J, Steinman RM. Dendritic cells and the control of immunity. Nature. (1998) 392:245-52. doi: 10.1038/32588

2. Gallo PM, Gallucci S. The dendritic cell response to classic, emerging, and homeostatic danger signals. Implications for autoimmunity. Front Immunol. (2013) 4:138. doi: 10.3389/fimmu.2013.00138

3. Nace G, Evankovich J, Eid R, Tsung A. Dendritic cells and damageassociated molecular patterns: endogenous danger signals linking innate and adaptive immunity. J Innate Immun. (2012) 4:6-15. doi: 10.1159/000 334245

4. Bonasio R, von Andrian UH. Generation, migration and function of circulating dendritic cells. Curr Opin Immunol. (2006) 18:503-11. doi: 10.1016/j.coi.2006.05.011 
5. Bloy N, Pol J, Aranda F, Eggermont A, Cremer I, Fridman WH, et al. Trial watch: dendritic cell-based anticancer therapy. Oncoimmunology. (2014) 3:e963424. doi: 10.4161/21624011.2014.963424

6. Garg AD, Vara Perez M, Schaaf M, Agostinis P, Zitvogel L, Kroemer $\mathrm{G}$, et al. Trial watch: dendritic cell-based anticancer immunotherapy. Oncoimmunology. (2017) 6:e1328341. doi: 10.1080/2162402X.2017.1328341

7. Vacchelli E, Vitale I, Eggermont A, Fridman WH, Fucikova J, Cremer I, et al. Trial watch: dendritic cell-based interventions for cancer therapy. Oncoimmunology. (2013) 2:e25771. doi: 10.4161/onci.25771

8. Anguille S, Smits EL, Lion E, van Tendeloo VF, Berneman ZN. Clinical use of dendritic cells for cancer therapy. Lancet Oncol. (2014) 15:e257-67. doi: 10.1016/S1470-2045(13)70585-0

9. Koski GK, Cohen PA, Roses RE, Xu S, Czerniecki BJ. Reengineering dendritic cell-based anti-cancer vaccines. Immunol Rev. (2008) 222:256-76. doi: 10.1111/j.1600-065X.2008.00617.x

10. Lee AW, Truong T, Bickham K, Fonteneau JF, Larsson M, Da Silva I, et al. A clinical grade cocktail of cytokines and PGE2 results in uniform maturation of human monocyte-derived dendritic cells: implications for immunotherapy. Vaccine. (2002) 20(Suppl. 4):A8-22. doi: 10.1016/S0264-410X(02)00382-1

11. Scandella E, Men Y, Gillessen S, Forster R, Groettrup M. Prostaglandin E2 is a key factor for CCR7 surface expression and migration of monocyte-derived dendritic cells. Blood. (2002) 100:1354-61. doi: 10.1182/blood-2001-11-0017

12. Krause P, Bruckner M, Uermosi C, Singer E, Groettrup M, Legler DF. Prostaglandin E(2) enhances T-cell proliferation by inducing the costimulatory molecules OX40L, CD70, and 4-1BBL on dendritic cells. Blood. (2009) 113:2451-60. doi: 10.1182/blood-2008-05-157123

13. Jongmans W, Tiemessen DM, van Vlodrop IJ, Mulders PF, Oosterwijk E. Th1-polarizing capacity of clinical-grade dendritic cells is triggered by ribomunyl but is compromised by PGE2: the importance of maturation cocktails. J Immunother. (2005) 28:480-7. doi: 10.1097/01.cji.0000171290.78495.66

14. Krause P, Singer E, Darley PI, Klebensberger J, Groettrup M, Legler DF. Prostaglandin E2 is a key factor for monocyte-derived dendritic cell maturation: enhanced T cell stimulatory capacity despite IDO. J Leukoc Biol. (2007) 82:1106-14. doi: 10.1189/jlb.0905519

15. Morelli AE, Thomson AW. Dendritic cells under the spell of prostaglandins. Trends Immunol. (2003) 24:108-11. doi: 10.1016/S1471-4906(03)00023-1

16. Carreno BM, Becker-Hapak M, Huang A, Chan M, Alyasiry A, Lie WR, et al. IL-12p70-producing patient DC vaccine elicits Tc1-polarized immunity. $J$ Clin Invest. (2013) 123:3383-94. doi: 10.1172/JCI68395

17. Mailliard RB, Wankowicz-Kalinska A, Cai Q, Wesa A, Hilkens CM, Kapsenberg ML, et al. alpha-type-1 polarized dendritic cells: a novel immunization tool with optimized CTL-inducing activity. Cancer Res. (2004) 64:5934-7. doi: 10.1158/0008-5472.CAN-04-1261

18. Kolanowski ST, Sritharan L, Lissenberg-Thunnissen SN, Van Schijndel GM, Van Ham SM, ten Brinke A. Comparison of media and serum supplementation for generation of monophosphoryl lipid a/interferongamma-matured type I dendritic cells for immunotherapy. Cytotherapy. (2014) 16:826-34. doi: 10.1016/j.jcyt.2013.12.005

19. Kantoff PW, Higano CS, Shore ND, Berger ER, Small EJ, Penson DF, et al. Sipuleucel-T immunotherapy for castration-resistant prostate cancer. N Engl J Med. (2010) 363:411-22. doi: 10.1056/NEJMoa1001294

20. Grenier JM, Yeung ST, Khanna KM. Combination immunotherapy: taking cancer vaccines to the next level. Front Immunol. (2018) 9:610. doi: 10.3389/fimmu.2018.00610

21. Joyce JA, Fearon DT. T cell exclusion, immune privilege, and the tumor microenvironment. Science. (2015) 348:74-80. doi: 10.1126/science.aaa6204

22. Kroemer G, Galluzzi L, Kepp O, Zitvogel L. Immunogenic cell death in cancer therapy. Annu Rev Immunol. (2013) 31:51-72. doi: 10.1146/annurev-immunol-032712-100008

23. Scarlett UK, Rutkowski MR, Rauwerdink AM, Fields J, Escovar-Fadul X, Baird J, et al. Ovarian cancer progression is controlled by phenotypic changes in dendritic cells. J Exp Med. (2012) 209:495-506. doi: 10.1084/jem.20111413

24. Tomihara K, Guo M, Shin T, Sun X, Ludwig SM, Brumlik MJ, et al. Antigen-specific immunity and cross-priming by epithelial ovarian carcinoma-induced CD11b(+)Gr-1(+) cells. J Immunol. (2010) 184:615160. doi: 10.4049/jimmunol.0903519
25. Chaput N, Conforti R, Viaud S, Spatz A, Zitvogel L. The Janus face of dendritic cells in cancer. Oncogene. (2008) 27:5920-31. doi: 10.1038 /onc. 2008.270

26. Taieb J, Chaput N, Menard C, Apetoh L, Ullrich E, Bonmort M, et al. A novel dendritic cell subset involved in tumor immunosurveillance. Nat Med. (2006) 12:214-9. doi: 10.1038/nm1356

27. Ma Y, Adjemian S, Mattarollo SR, Yamazaki T, Aymeric L, Yang H, et al. Anticancer chemotherapy-induced intratumoral recruitment and differentiation of antigen-presenting cells. Immunity. (2013) 38:729-41. doi: 10.1016/j.immuni.2013.03.003

28. Noessner E, Brech D, Mendler AN, Masouris I, Schlenker R, Prinz PU. Intratumoral alterations of dendritic-cell differentiation and CD8 $(+)$ T-cell anergy are immune escape mechanisms of clear cell renal cell carcinoma. Oncoimmunology. (2012) 1:1451-3. doi: 10.4161/onci.21356

29. Sisirak V, Faget J, Vey N, Blay JY, Menetrier-Caux C, Caux C, et al. Plasmacytoid dendritic cells deficient in IFNalpha production promote the amplification of FOXP3(+) regulatory T cells and are associated with poor prognosis in breast cancer patients. Oncoimmunology. (2013) 2:e22338. doi: 10.4161/onci.22338

30. Kumar C, Kohli S, Chiliveru S, Bapsy PP, Jain M, Suresh Attili VS, et al. A retrospective analysis comparing $\operatorname{APCEDEN}(\mathrm{R})$ dendritic cell immunotherapy with best supportive care in refractory cancer. Immunotherapy. (2017) 9:889-97. doi: 10.2217/imt-2017-0064

31. Bapsy PP, Sharan B, Kumar C, Das RP, Rangarajan B, Jain M, et al. Openlabel, multi-center, non-randomized, single-arm study to evaluate the safety and efficacy of dendritic cell immunotherapy in patients with refractory solid malignancies, on supportive care. Cytotherapy. (2014) 16:234-44. doi: 10.1016/j.jcyt.2013.11.013

32. Robbins SH, Walzer T, Dembele D, Thibault C, Defays A, Bessou G, et al. Novel insights into the relationships between dendritic cell subsets in human and mouse revealed by genome-wide expression profiling. Genome Biol. (2008) 9:R17. doi: 10.1186/gb-2008-9-1-r17

33. Crozat K, Guiton R, Guilliams M, Henri S, Baranek T, Schwartz-Cornil $\mathrm{I}$, et al. Comparative genomics as a tool to reveal functional equivalences between human and mouse dendritic cell subsets. Immunol Rev. (2010) 234:177-98. doi: 10.1111/j.0105-2896.2009.00868.x

34. Guilliams M, Henri S, Tamoutounour S, Ardouin L, Schwartz-Cornil I, Dalod M, et al. From skin dendritic cells to a simplified classification of human and mouse dendritic cell subsets. Eur J Immunol. (2010) 40:2089-94. doi: 10.1002/eji.201040498

35. Haniffa M, Shin A, Bigley V, McGovern N, Teo P, See P, et al. Human tissues contain CD141hi cross-presenting dendritic cells with functional homology to mouse CD103+ nonlymphoid dendritic cells. Immunity. (2012) 37:60-73. doi: 10.1016/j.immuni.2012.04.012

36. Lundberg K, Albrekt AS, Nelissen I, Santegoets S, de Gruijl TD, Gibbs S, et al. Transcriptional profiling of human dendritic cell populations and models-unique profiles of in vitro dendritic cells and implications on functionality and applicability. PLOS ONE. (2013) 8:e52875. doi: 10.1371/journal.pone.0052875

37. Ziegler-Heitbrock L, Ancuta P, Crowe S, Dalod M, Grau V, Hart DN, et al. Nomenclature of monocytes and dendritic cells in blood. Blood. (2010) 116:e74-80. doi: 10.1182/blood-2010-02-258558

38. Joffre OP, Segura E, Savina A, Amigorena S. Cross-presentation by dendritic cells. Nat Rev Immunol. (2012) 12:557-69. doi: 10.1038/nri3254

39. Poulin LF, Salio M, Griessinger E, Anjos-Afonso F, Craciun L, Chen JL, et al. Characterization of human DNGR-1+ BDCA3+ leukocytes as putative equivalents of mouse CD8alpha+ dendritic cells. J Exp Med. (2010) 207:1261-71. doi: 10.1084/jem.20092618

40. Sancho D, Joffre OP, Keller AM, Rogers NC, Martinez D, Hernanz-Falcon $\mathrm{P}$, et al. Identification of a dendritic cell receptor that couples sensing of necrosis to immunity. Nature. (2009) 458:899-903. doi: 10.1038/natu re07750

41. Dorner BG, Dorner MB, Zhou X, Opitz C, Mora A, Guttler S, et al. Selective expression of the chemokine receptor XCR1 on cross-presenting dendritic cells determines cooperation with CD8 + T cells. Immunity. (2009) 31:82333. doi: 10.1016/j.immuni.2009.08.027

42. Jongbloed SL, Kassianos AJ, McDonald KJ, Clark GJ, Ju X, Angel CE, et al. Human CD141+ (BDCA-3)+ dendritic cells (DCs) represent a unique 
myeloid DC subset that cross-presents necrotic cell antigens. J Exp Med. (2010) 207:1247-60. doi: 10.1084/jem.20092140

43. Bachem A, Guttler S, Hartung E, Ebstein F, Schaefer M, Tannert A, et al. Superior antigen cross-presentation and XCR1 expression define human CD11c+CD141+ cells as homologues of mouse CD8+ dendritic cells. J Exp Med. (2010) 207:1273-81. doi: 10.1084/jem.20100348

44. Perussia B, Fanning V, Trinchieri G. A leukocyte subset bearing HLA-DR antigens is responsible for in vitro alpha interferon production in response to viruses. Nat Immun Cell Growth Regul. (1985) 4:120-37.

45. Moseman EA, Liang X, Dawson AJ, Panoskaltsis-Mortari A, Krieg AM, Liu YJ, et al. Human plasmacytoid dendritic cells activated by CpG oligodeoxynucleotides induce the generation of $\mathrm{CD} 4+\mathrm{CD} 25+$ regulatory $\mathrm{T}$ cells. J Immunol. (2004) 173:4433-42. doi: 10.4049/jimmunol.173.7.4433

46. Ito $\mathrm{T}$, Yang $\mathrm{M}$, Wang $\mathrm{YH}$, Lande $\mathrm{R}$, Gregorio J, Perng OA, et al. Plasmacytoid dendritic cells prime IL-10-producing $\mathrm{T}$ regulatory cells by inducible costimulator ligand. J Exp Med. (2007) 204:105-15. doi: $10.1084 /$ jem.20061660

47. Bjorck P, Leong HX, Engleman EG. Plasmacytoid dendritic cell dichotomy: identification of IFN-alpha producing cells as a phenotypically and functionally distinct subset. J Immunol. (2011) 186:1477-85. doi: 10.4049/jimmunol.1000454

48. Reizis B, Colonna M, Trinchieri G, Barrat F, Gilliet M. Plasmacytoid dendritic cells: one-trick ponies or workhorses of the immune system? Nat Rev Immunol. (2011) 11:558-65. doi: 10.1038/nri3027

49. Vermi W, Soncini M, Melocchi L, Sozzani S, Facchetti F. Plasmacytoid dendritic cells and cancer. J Leukoc Biol. (2011) 90:681-90. doi: $10.1189 / \mathrm{jlb} .0411190$

50. Guilliams M, Dutertre CA, Scott CL, McGovern N, Sichien D, Chakarov S, et al. Unsupervised high-dimensional analysis aligns dendritic cells across tissues and species. Immunity. (2016) 45:669-84. doi: 10.1016/j.immuni.2016.08.015

51. Villani AC, Satija R, Reynolds G, Sarkizova S, Shekhar K, Fletcher J, et al. Single-cell RNA-seq reveals new types of human blood dendritic cells, monocytes, and progenitors. Science. (2017) 356:eaah4573. doi: 10.1126/science.aah4573

52. Hsu FJ, Benike C, Fagnoni F, Liles TM, Czerwinski D, Taidi B, et al. Vaccination of patients with B-cell lymphoma using autologous antigenpulsed dendritic cells. Nat Med. (1996) 2:52-8. doi: 10.1038/nm0196-52

53. Palucka AK, Ueno H, Connolly J, Kerneis-Norvell F, Blanck JP, Johnston DA, et al. Dendritic cells loaded with killed allogeneic melanoma cells can induce objective clinical responses and MART-1 specific CD8+ T-cell immunity. $J$ Immunother. (2006) 29:545-57. doi: 10.1097/01.cji.0000211309.90621.8b

54. Palucka K, Banchereau J. Cancer immunotherapy via dendritic cells. Nat Rev Cancer. (2012) 12:265-77. doi: 10.1038/nrc3258

55. Leon B, Lopez-Bravo M, Ardavin C. Monocyte-derived dendritic cells formed at the infection site control the induction of protective $\mathrm{T}$ helper 1 responses against leishmania. Immunity. (2007) 26:519-31. doi: 10.1016/j.immuni.2007.01.017

56. Ebner S, Ratzinger G, Krosbacher B, Schmuth M, Weiss A, Reider D, et al. Production of IL-12 by human monocyte-derived dendritic cells is optimal when the stimulus is given at the onset of maturation, and is further enhanced by IL-4. J Immunol. (2001) 166:633-41. doi: 10.4049/jimmunol.166.1.633

57. Sallusto F, Lanzavecchia A. Efficient presentation of soluble antigen by cultured human dendritic cells is maintained by granulocyte/macrophage colony-stimulating factor plus interleukin 4 and downregulated by tumor necrosis factor alpha. J Exp Med. (1994) 179:1109-18. doi: 10.1084/jem.179.4.1109

58. Osugi Y, Vuckovic S, Hart DN. Myeloid blood CD11c(+) dendritic cells and monocyte-derived dendritic cells differ in their ability to stimulate $\mathrm{T}$ lymphocytes. Blood. (2002) 100:2858-66. doi: 10.1182/blood.V100.8.2858

59. Tel J, Aarntzen EH, Baba T, Schreibelt G, Schulte BM, Benitez-Ribas D, et al. Natural human plasmacytoid dendritic cells induce antigen-specific T-cell responses in melanoma patients. Cancer Res. (2013) 73:1063-75. doi: 10.1158/0008-5472.CAN-12-2583

60. Prue RL, Vari F, Radford KJ, Tong H, Hardy MY, D’Rozario R, et al. A phase I clinical trial of CD1c (BDCA-1)+ dendritic cells pulsed with HLA-A*0201 peptides for immunotherapy of metastatic hormone refractory prostate cancer. J Immunother. (2015) 38:71-6. doi: 10.1097/CJI.0000000000000063

61. Hsu JL, Bryant CE, Papadimitrious MS, Kong B, Gasiorowski RE, Orellana D, et al. A blood dendritic cell vaccine for acute myeloid leukemia expands antitumor T cell responses at remission. Oncoimmunology. (2018) 7:e1419114. doi: 10.1080/2162402X.2017.1419114

62. Balan S, Ollion V, Colletti N, Chelbi R, Montanana-Sanchis F, Liu H, et al. Human XCR1+ dendritic cells derived in vitro from CD34+ progenitors closely resemble blood dendritic cells, including their adjuvant responsiveness, contrary to monocyte-derived dendritic cells. J Immunol. (2014) 193:1622-35. doi: 10.4049/jimmunol.1401243

63. Wimmers F, Schreibelt G, Skold AE, Figdor CG, De Vries IJ. Paradigm shift in dendritic cell-based immunotherapy: from in vitro generated monocytederived DCs to naturally circulating DC subsets. Front Immunol. (2014) 5:165. doi: 10.3389/fimmu.2014.00165

64. Hu J, Kinn J, Zirakzadeh AA, Sherif A, Norstedt G, Wikstrom AC, et al. The effects of chemotherapeutic drugs on human monocyte-derived dendritic cell differentiation and antigen presentation. Clin Exp Immunol. (2013) 172:490-9. doi: 10.1111/cei.12060

65. Nguyen NT, Kimura A, Nakahama T, Chinen I, Masuda K, Nohara $\mathrm{K}$, et al. Aryl hydrocarbon receptor negatively regulates dendritic cell immunogenicity via a kynurenine-dependent mechanism. Proc Natl Acad Sci USA. (2010) 107:19961-6. doi: 10.1073/pnas.1014465107

66. Belladonna ML, Volpi C, Bianchi R, Vacca C, Orabona C, Pallotta MT, et al. Cutting edge: autocrine TGF-beta sustains default tolerogenesis by IDO-competent dendritic cells. J Immunol. (2008) 181:5194-8. doi: $10.4049 /$ jimmunol.181.8.5194

67. Liu Q, Zhang C, Sun A, Zheng Y, Wang L, Cao X. Tumor-educated CD11bhighIalow regulatory dendritic cells suppress $\mathrm{T}$ cell response through arginase I. J Immunol. (2009) 182:6207-16. doi: 10.4049/jimmunol.0803926

68. Steinbrink K, Wolfl M, Jonuleit H, Knop J, Enk AH. Induction of tolerance by IL-10-treated dendritic cells. J Immunol. (1997) 159:4772-80.

69. Bellone G, Carbone A, Smirne C, Scirelli T, Buffolino A, Novarino A, et al. Cooperative induction of a tolerogenic dendritic cell phenotype by cytokines secreted by pancreatic carcinoma cells. J Immunol. (2006) 177:3448-60. doi: 10.4049/jimmunol.177.5.3448

70. Cubillos-Ruiz JR, Baird JR, Tesone AJ, Rutkowski MR, Scarlett UK, Camposeco-Jacobs AL, et al. Reprogramming tumor-associated dendritic cells in vivo using miRNA mimetics triggers protective immunity against ovarian cancer. Cancer Res. (2012) 72:1683-93. doi: 10.1158/0008-5472.CAN-11-3160

71. Zou W, Machelon V, Coulomb-L'Hermin A, Borvak J, Nome F, Isaeva T, et al. Stromal-derived factor-1 in human tumors recruits and alters the function of plasmacytoid precursor dendritic cells. Nat Med. (2001) 7:133946. doi: 10.1038/nm1201-1339

72. Jiang YP, Wu XH, Shi B, Wu WX, Yin GR. Expression of chemokine CXCL12 and its receptor CXCR4 in human epithelial ovarian cancer: an independent prognostic factor for tumor progression. Gynecol Oncol. (2006) 103:226-33. doi: 10.1016/j.ygyno.2006.02.036

73. Gabrilovich DI, Chen HL, Girgis KR, Cunningham HT, Meny GM, Nadaf $S$, et al. Production of vascular endothelial growth factor by human tumors inhibits the functional maturation of dendritic cells. Nat Med. (1996) 2:1096103. doi: $10.1038 / \mathrm{nm} 1096-1096$

74. Gabrilovich D, Ishida T, Oyama T, Ran S, Kravtsov V, Nadaf S, et al. Vascular endothelial growth factor inhibits the development of dendritic cells and dramatically affects the differentiation of multiple hematopoietic lineages in vivo. Blood. (1998) 92:4150-66.

75. Lissoni P, Malugani F, Bonfanti A, Bucovec R, Secondino S, Brivio F, et al. Abnormally enhanced blood concentrations of vascular endothelial growth factor (VEGF) in metastatic cancer patients and their relation to circulating dendritic cells, IL-12 and endothelin-1. J Biol Regul Homeost Agents. (2001) 15:140-4.

76. Fan XH, Han BH, Dong QG, Sha HF, Bao GL, Liao ML. Vascular endothelial growth factor inhibits dendritic cells from patients with non-small cell lung carcinoma. Zhonghua Jie He He Hu Xi Za Zhi. (2003) 26:539-43.

77. Takahashi A, Kono K, Ichihara F, Sugai H, Fujii H, Matsumoto Y. Vascular endothelial growth factor inhibits maturation of dendritic cells induced by 
lipopolysaccharide, but not by proinflammatory cytokines. Cancer Immunol Immunother. (2004) 53:543-50. doi: 10.1007/s00262-003-0466-8

78. Bandola-Simon J, Roche PA. Dysfunction of antigen processing and presentation by dendritic cells in cancer. Mol Immunol. (2018). doi: 10.1016/j.molimm.2018.03.025

79. Pinzon-Charry A, Maxwell T, Lopez JA. Dendritic cell dysfunction in cancer: a mechanism for immunosuppression. Immunol Cell Biol. (2005) 83:451-61. doi: 10.1111/j.1440-1711.2005.01371.x

80. Gabrilovich DI, Ostrand-Rosenberg S, Bronte V. Coordinated regulation of myeloid cells by tumours. Nat Rev Immunol. (2012) 12:253-68. doi: $10.1038 / \mathrm{nri3} 175$

81. Bronte V, Serafini P, Apolloni E, Zanovello P. Tumor-induced immune dysfunctions caused by myeloid suppressor cells. J Immunother. (2001) 24:431-46. doi: 10.1097/00002371-200111000-00001

82. Curiel TJ, Wei S, Dong H, Alvarez X, Cheng P, Mottram P, et al. Blockade of B7-H1 improves myeloid dendritic cell-mediated antitumor immunity. Nat Med. (2003) 9:562-7. doi: 10.1038/nm863

83. Conrad C, Gregorio J, Wang YH, Ito T, Meller S, Hanabuchi S, et al. Plasmacytoid dendritic cells promote immunosuppression in ovarian cancer via ICOS costimulation of Foxp3(+) T-regulatory cells. Cancer Res. (2012) 72:5240-9. doi: 10.1158/0008-5472.CAN-12-2271

84. Treilleux I, Blay JY, Bendriss-Vermare N, Ray-Coquard I, Bachelot T, Guastalla JP, et al. Dendritic cell infiltration and prognosis of early stage breast cancer. Clin Cancer Res. (2004) 10:7466-74. doi: 10.1158/1078-0432.CCR-04-0684

85. Gabrilovich D. Mechanisms and functional significance of tumourinduced dendritic-cell defects. Nat Rev Immunol. (2004) 4:941-52. doi: 10.1038/nri1498

86. Meyer MA, Baer JM, Knolhoff BL, Nywening TM, Panni RZ, Su X, et al. Breast and pancreatic cancer interrupt IRF8-dependent dendritic cell development to overcome immune surveillance. Nat Commun. (2018) 9:1250. doi: 10.1038/s41467-018-03600-6

87. Herber DL, Cao W, Nefedova Y, Novitskiy SV, Nagaraj S, Tyurin VA, et al. Lipid accumulation and dendritic cell dysfunction in cancer. Nat Med. (2010) 16:880-6. doi: $10.1038 / \mathrm{nm} .2172$

88. Almand B, Resser JR, Lindman B, Nadaf S, Clark JI, Kwon ED, et al. Clinical significance of defective dendritic cell differentiation in cancer. Clin Cancer Res. (2000) 6:1755-66.

89. Chiba S, Baghdadi M, Akiba H, Yoshiyama H, Kinoshita I, Dosaka-Akita H, et al. Tumor-infiltrating DCs suppress nucleic acid-mediated innate immune responses through interactions between the receptor TIM-3 and the alarmin HMGB1. Nat Immunol. (2012) 13:832-42. doi: 10.1038/ni.2376

90. Krempski J, Karyampudi L, Behrens MD, Erskine CL, Hartmann L, Dong $\mathrm{H}$, et al. Tumor-infiltrating programmed death receptor-1+ dendritic cells mediate immune suppression in ovarian cancer. J Immunol. (2011) 186:6905-13. doi: 10.4049/jimmunol.1100274

91. Norian LA, Rodriguez PC, O’Mara LA, Zabaleta J, Ochoa AC, Cella $\mathrm{M}$, et al. Tumor-infiltrating regulatory dendritic cells inhibit CD8+ T cell function via L-arginine metabolism. Cancer Res. (2009) 69:3086-94. doi: 10.1158/0008-5472.CAN-08-2826

92. Cubillos-Ruiz JR, Martinez D, Scarlett UK, Rutkowski MR, Nesbeth YC, Camposeco-Jacobs AL, et al. CD277 is a negative co-stimulatory molecule universally expressed by ovarian cancer microenvironmental cells. Oncotarget. (2010) 1:329-38. doi: 10.18632/oncotarget.165

93. Karyampudi L, Lamichhane P, Krempski J, Kalli KR, Behrens MD, Vargas DM, et al. PD-1 blunts the function of ovarian tumor-infiltrating dendritic cells by inactivating NF-kappaB. Cancer Res. (2016) 76:239-50. doi: 10.1158/0008-5472.CAN-15-0748

94. Jing Y, Shaheen E, Drake RR, Chen N, Gravenstein S, Deng Y. Aging is associated with a numerical and functional decline in plasmacytoid dendritic cells, whereas myeloid dendritic cells are relatively unaltered in human peripheral blood. Hum Immunol. (2009) 70:777-84. doi: 10.1016/j.humimm.2009.07.005

95. Rahmatpanah F, Agrawal S, Scarfone VM, Kapadia S, Mercola D, Agrawal A. Transcriptional profiling of age-associated gene expression changes in human circulatory CD1c+ myeloid dendritic cell subset. J Gerontol A Biol Sci Med Sci. (2018) 74:9-15. doi: 10.1093/gerona/gly106
96. Cintolo JA, Datta J, Mathew SJ, Czerniecki BJ. Dendritic cell-based vaccines: barriers and opportunities. Future Oncol. (2012) 8:1273-99. doi: $10.2217 /$ fon. 12.125

97. Scarlett UK, Cubillos-Ruiz JR, Nesbeth YC, Martinez DG, Engle $\mathrm{X}$, Gewirtz AT, et al. In situ stimulation of $\mathrm{CD} 40$ and toll-like receptor 3 transforms ovarian cancer-infiltrating dendritic cells from immunosuppressive to immunostimulatory cells. Cancer Res. (2009) 69:7329-37. doi: 10.1158/0008-5472.CAN-09-0835

98. Di Pucchio T, Pilla L, Capone I, Ferrantini M, Montefiore E, Urbani F, et al. Immunization of stage IV melanoma patients with melan-A/MART-1 and gp100 peptides plus IFN-alpha results in the activation of specific CD8(+) T cells and monocyte/dendritic cell precursors. Cancer Res. (2006) 66:4943-51. doi: 10.1158/0008-5472.CAN-05-3396

99. Sakakibara M, Kanto T, Hayakawa M, Kuroda S, Miyatake H, Itose I, et al. Comprehensive immunological analyses of colorectal cancer patients in the phase I/II study of quickly matured dendritic cell vaccine pulsed with carcinoembryonic antigen peptide. Cancer Immunol Immunother. (2011) 60:1565-75. doi: 10.1007/s00262-011-1051-1

100. Morse MA, Niedzwiecki D, Marshall JL, Garrett C, Chang DZ, Aklilu M, et al. A randomized phase II study of immunization with dendritic cells modified with poxvectors encoding CEA and MUC1 compared with the same poxvectors plus GM-CSF for resected metastatic colorectal cancer. Ann Surg. (2013) 258:879-86. doi: 10.1097/SLA.0b013e318292919e

101. Schuler PJ, Harasymczuk M, Visus C, Deleo A, Trivedi S, Lei Y, et al. Phase I dendritic cell p53 peptide vaccine for head and neck cancer. Clin Cancer Res. (2014) 20:2433-44. doi: 10.1158/1078-0432.CCR-13-2617

102. Gasser O, Sharples KJ, Barrow C, Williams GM, Bauer E, Wood CE, et al. A phase I vaccination study with dendritic cells loaded with NY-ESO-1 and alpha-galactosylceramide: induction of polyfunctional $\mathrm{T}$ cells in highrisk melanoma patients. Cancer Immunol Immunother. (2018) 67:285-98. doi: 10.1007/s00262-017-2085-9

103. Wilgenhof S, Van Nuffel AM, Corthals J, Heirman C, Tuyaerts S, Benteyn $D$, et al. Therapeutic vaccination with an autologous mRNA electroporated dendritic cell vaccine in patients with advanced melanoma. J Immunother. (2011) 34:448-56. doi: 10.1097/CJI.0b013e31821dcb31

104. Oshita C, Takikawa M, Kume A, Miyata H, Ashizawa T, Iizuka A, et al. Dendritic cell-based vaccination in metastatic melanoma patients: phase II clinical trial. Oncol Rep. (2012) 28:1131-8. doi: 10.3892/or.2012.1956

105. Kouiavskaia DV, Berard CA, Datena E, Hussain A, Dawson N, Klyushnenkova EN, et al. Vaccination with agonist peptide PSA: 154163 (155L) derived from prostate specific antigen induced CD8 T-cell response to the native peptide PSA: $154-163$ but failed to induce the reactivity against tumor targets expressing PSA: a phase 2 study in patients with recurrent prostate cancer. J Immunother. (2009) 32:655-66. doi: 10.1097/CJI.0b013e3181a80e0d

106. Lesterhuis WJ, Aarntzen EH, De Vries IJ, Schuurhuis DH, Figdor CG, Adema GJ, et al. Dendritic cell vaccines in melanoma: from promise to proof? Crit Rev Oncol Hematol. (2008) 66:118-34. doi: 10.1016/j.critrevonc.2007.12.007

107. Mohme M, Riethdorf S, Pantel K. Circulating and disseminated tumour cells - mechanisms of immune surveillance and escape. Nat Rev Clin Oncol. (2017) 14:155-67. doi: 10.1038/nrclinonc.2016.144

108. Boisguerin V, Castle JC, Loewer M, Diekmann J, Mueller F, Britten $\mathrm{CM}$, et al. Translation of genomics-guided RNA-based personalised cancer vaccines: towards the bedside. Br J Cancer. (2014) 111:1469-75. doi: $10.1038 /$ bjc. 2013.820

109. Bassani-Sternberg M, Braunlein E, Klar R, Engleitner T, Sinitcyn P, Audehm $S$, et al. Direct identification of clinically relevant neoepitopes presented on native human melanoma tissue by mass spectrometry. Nat Commun. (2016) 7:13404. doi: 10.1038/ncomms13404

110. Carreno BM, Magrini V, Becker-Hapak M, Kaabinejadian S, Hundal J, Petti AA, et al. A dendritic cell vaccine increases the breadth and diversity of melanoma neoantigen-specific T cells. Science. (2015) 348:803-8. doi: $10.1126 /$ science.aaa3828

111. Ott PA, Elez E, Hiret S, Kim DW, Morosky A, Saraf S, et al. Pembrolizumab in patients with extensive-stage small-cell lung cancer: results from the phase Ib KEYNOTE-028 study. J Clin Oncol. (2017) 35:3823-9. doi: 10.1200/JCO.2017.72.5069 
112. Sahin U, Derhovanessian E, Miller M, Kloke BP, Simon P, Lower M, et al. Personalized RNA mutanome vaccines mobilize poly-specific therapeutic immunity against cancer. Nature. (2017) 547:222-6. doi: 10.1038/nature23003

113. Alfaro C, Perez-Gracia JL, Suarez N, Rodriguez J, Fernandez de Sanmamed M, Sangro B, et al. Pilot clinical trial of type 1 dendritic cells loaded with autologous tumor lysates combined with GM-CSF, pegylated IFN, and cyclophosphamide for metastatic cancer patients. J Immunol. (2011) 187:6130-42. doi: 10.4049/jimmunol.1102209

114. Nestle FO, Alijagic S, Gilliet M, Sun Y, Grabbe S, Dummer R, et al. Vaccination of melanoma patients with peptide- or tumor lysate-pulsed dendritic cells. Nat Med. (1998) 4:328-32. doi: 10.1038/nm0398-328

115. Chiang CL, Coukos G, Kandalaft LE. Whole tumor antigen vaccines: where are we? Vaccines (Basel). (2015) 3:344-72. doi: 10.3390/vaccines3020344

116. Marcinkiewicz J, Chain BM, Olszowska E, Olszowski S, Zgliczynski JM. Enhancement of immunogenic properties of ovalbumin as a result of its chlorination. Int J Biochem. (1991) 23:1393-5. doi: 10.1016/0020-711X(91)90280-Z

117. Marcinkiewicz J, Olszowska E, Olszowski S, Zgliczynski JM. Enhancement of trinitrophenyl-specific humoral response to TNP proteins as the result of carrier chlorination. Immunology. (1992) 76:385-8.

118. Allison ME, Fearon DT. Enhanced immunogenicity of aldehydebearing antigens: a possible link between innate and adaptive immunity. Eur J Immunol. (2000) 30:2881-7. doi: 10.1002/15214141(200010)30:10<2881::AID-IMMU2881>3.0.CO;2-9

119. Benencia F, Courreges MC, Coukos G. Whole tumor antigen vaccination using dendritic cells: comparison of RNA electroporation and pulsing with UV-irradiated tumor cells. J Transl Med. (2008) 6:21. doi: 10.1186/1479-5876-6-21

120. Courreges MC, Benencia F, Conejo-Garcia JR, Zhang L, Coukos G. Preparation of apoptotic tumor cells with replication-incompetent HSV augments the efficacy of dendritic cell vaccines. Cancer Gene Ther. (2006) 13:182-93. doi: 10.1038/sj.cgt.7700888

121. Chiang CL, Kandalaft LE, Tanyi J, Hagemann AR, Motz GT, Svoronos $\mathrm{N}$, et al. A dendritic cell vaccine pulsed with autologous hypochlorous acid-oxidized ovarian cancer lysate primes effective broad antitumor immunity: from bench to bedside. Clin Cancer Res. (2013) 19:4801-15. doi: 10.1158/1078-0432.CCR-13-1185

122. Tanyi JL, Bobisse S, Ophir E, Tuyaerts S, Roberti A, Genolet R, et al. Personalized cancer vaccine effectively mobilizes antitumor $\mathrm{T}$ cell immunity in ovarian cancer. Sci Transl Med. (2018) 10(436). doi: 10.1126/scitranslmed.aao5931

123. Liau LM, Ashkan K, Tran DD, Campian JL, Trusheim JE, Cobbs CS, et al. First results on survival from a large phase 3 clinical trial of an autologous dendritic cell vaccine in newly diagnosed glioblastoma. J Transl Med. (2018) 16:142. doi: 10.1186/s12967-018-1507-6

124. Garcia-Salum T, Villablanca A, Matthaus F, Tittarelli A, Baeza M, Pereda C, et al. Molecular signatures associated with tumor-specific immune response in melanoma patients treated with dendritic cell-based immunotherapy. Oncotarget. (2018) 9:17014-27. doi: 10.18632/oncotarget. 24795

125. Pellegatta S, Eoli M, Cuccarini V, Anghileri E, Pollo B, Pessina S, et al. Survival gain in glioblastoma patients treated with dendritic cell immunotherapy is associated with increased NK but not CD8(+) T cell activation in the presence of adjuvant temozolomide. Oncoimmunology. (2018) 7:e1412901. doi: 10.1080/2162402X.2017.1412901

126. Yang Z, Deng F, Meng L. Effect of dendritic cell immunotherapy on distribution of dendritic cell subsets in non-small cell lung cancer. Exp Ther Med. (2018) 15:4856-60. doi: 10.3892/etm.2018.6010

127. Gooden MJ, de Bock GH, Leffers N, Daemen T, Nijman HW. The prognostic influence of tumour-infiltrating lymphocytes in cancer: a systematic review with meta-analysis. Br J Cancer. (2011) 105:93-103. doi: $10.1038 /$ bjc. 2011.189
128. Zhang L, Conejo-Garcia JR, Katsaros D, Gimotty PA, Massobrio M, Regnani $\mathrm{G}$, et al. Intratumoral T cells, recurrence, and survival in epithelial ovarian cancer. N Engl J Med. (2003) 348:203-13. doi: 10.1056/NEJMoa020177

129. Adams SF, Levine DA, Cadungog MG, Hammond R, Facciabene A, Olvera $\mathrm{N}$, et al. Intraepithelial T cells and tumor proliferation: impact on the benefit from surgical cytoreduction in advanced serous ovarian cancer. Cancer. (2009) 115:2891-902. doi: 10.1002/cncr.24317

130. Hamanishi J, Mandai M, Iwasaki M, Okazaki T, Tanaka Y, Yamaguchi K, et al. Programmed cell death 1 ligand 1 and tumor-infiltrating CD8 $+\mathrm{T}$ lymphocytes are prognostic factors of human ovarian cancer. Proc Natl Acad Sci USA. (2007) 104:3360-5. doi: 10.1073/pnas.0611533104

131. Sato E, Olson SH, Ahn J, Bundy B, Nishikawa H, Qian F, et al. Intraepithelial CD8+ tumor-infiltrating lymphocytes and a high CD8+/regulatory T cell ratio are associated with favorable prognosis in ovarian cancer. Proc Natl Acad Sci USA. (2005) 102:18538-43. doi: 10.1073/pnas.0509182102

132. Tomsova M, Melichar B, Sedlakova I, Steiner I. Prognostic significance of CD3 + tumor-infiltrating lymphocytes in ovarian carcinoma. Gynecol Oncol. (2008) 108:415-20. doi: 10.1016/j.ygyno.2007.10.016

133. Stumpf M, Hasenburg A, Riener MO, Jutting U, Wang C, Shen Y, et al. Intraepithelial CD8-positive $\mathrm{T}$ lymphocytes predict survival for patients with serous stage III ovarian carcinomas: relevance of clonal selection of T lymphocytes. Br J Cancer. (2009) 101:1513-21. doi: 10.1038/sj.bjc.6605274

134. Milne K, Kobel M, Kalloger SE, Barnes RO, Gao D, Gilks CB, et al. Systematic analysis of immune infiltrates in high-grade serous ovarian cancer reveals CD20, FoxP3 and TIA-1 as positive prognostic factors. PLoS ONE. (2009) 4:e6412. doi: 10.1371/journal.pone.0006412

135. Curiel TJ, Coukos G, Zou L, Alvarez X, Cheng P, Mottram P, et al. Specific recruitment of regulatory $\mathrm{T}$ cells in ovarian carcinoma fosters immune privilege and predicts reduced survival. Nat Med. (2004) 10:942-9. doi: $10.1038 / \mathrm{nm} 1093$

136. Preston CC, Maurer MJ, Oberg AL, Visscher DW, Kalli KR, Hartmann LC, et al. The ratios of CD8+ T cells to CD4+CD25+ FOXP3 + and FOXP3- T cells correlate with poor clinical outcome in human serous ovarian cancer. PLoS ONE. (2013) 8:e80063. doi: 10.1371/journal.pone.0080063

137. Knutson KL, Maurer MJ, Preston CC, Moysich KB, Goergen K, Hawthorne $\mathrm{KM}$, et al. Regulatory T cells, inherited variation, and clinical outcome in epithelial ovarian cancer. Cancer Immunol Immunother. (2015) 64:1495-504. doi: 10.1007/s00262-015-1753-x

138. Hsu M, Sedighim S, Wang T, Antonios JP, Everson RG, Tucker AM, et al. TCR Sequencing can identify and track glioma-infiltrating $\mathrm{T}$ cells after DC vaccination. Cancer Immunol Res. (2016) 4:412-8. doi: 10.1158/2326-6066.CIR-15-0240

139. Kirkwood JM, Lee S, Moschos SJ, Albertini MR, Michalak JC, Sander $C$, et al. Immunogenicity and antitumor effects of vaccination with peptide vaccine+/-granulocyte-monocyte colony-stimulating factor and/or IFN-alpha2b in advanced metastatic melanoma: eastern cooperative oncology group phase II trial E1696. Clin Cancer Res. (2009) 15:1443-51. doi: 10.1158/1078-0432.CCR-08-1231

140. Armitage EG, Barbas C. Metabolomics in cancer biomarker discovery: current trends and future perspectives. J Pharm Biomed Anal. (2014) 87:111. doi: 10.1016/j.jpba.2013.08.041

Conflict of Interest Statement: The authors declare that the research was conducted in the absence of any commercial or financial relationships that could be construed as a potential conflict of interest.

Copyright (C) 2019 Mastelic-Gavillet, Balint, Boudousquie, Gannon and Kandalaft. This is an open-access article distributed under the terms of the Creative Commons Attribution License (CC BY). The use, distribution or reproduction in other forums is permitted, provided the original author(s) and the copyright owner(s) are credited and that the original publication in this journal is cited, in accordance with accepted academic practice. No use, distribution or reproduction is permitted which does not comply with these terms. 